\title{
Firmness and Decay of Apples following Postharvest Pressure Infiltration of Calcium and Heat Treatment
}

\author{
Carl E. Sams \\ Department of Plant and Soil Science, University of Tennessee, Knoxville, TN 37901
}

William S. Conway and Judith A. Abbott

Beltsville Agricultural Research Center, Agricultural Research Service, U.S. Department of Agriculture, Beltsville, MD 20705

Russell J. Lewis

Department of Plant and Soil Science, University of Tennessee, Knoxville, TN 37901

\author{
Noach Ben-Shalom \\ Department of Food Science, The Volcani Center, Bet-Dagan 50250, Israel
}

Additional index words. $\mathrm{CaCl}_{2}$, Malus domestica, Penicillium expansum

\begin{abstract}
Heating 'Golden Delicious' apples (Malus domestica Borkh.) for 4 days at 38C or pressure-infiltrating them with a $4 \% \mathrm{CaCl}_{2}$ solution reduced decay and maintained fruit firmness during 6 months of storage at $0 \mathrm{C}$. Heating reduced decay caused by Penicillium expansum Link ex Thorn by $\approx 30 \%$, while pressure infiltration with $\mathrm{CaCl}_{2}$ reduced decay by $>60 \%$. Pressure infiltration with $\mathrm{CaCl}$, after heating reduced decay by $\approx 40 \%$. Pressure infiltration maintained firmness best $(>84$ $\mathrm{N}$ ), as measured with a manually driven electronic fruit-firmness probe, followed by heat and $\mathrm{CaCl}_{2}(76 \mathbf{~ N})$, heat alone (71 $\mathrm{N})$, and no treatment (control) $(60 \mathrm{~N})$. Force vs. deformation (FD) curves from a puncture test with a fruit-firmness probe mounted in a universal testing machine showed that fruit heated before storage were firmer than all nonheated fruit, except those pressure-infiltrated with $4 \% \mathrm{CaCl}_{2}$. However, FD curves also showed that apples pressure-infiltrated with $4 \% \mathrm{CaCl}_{2}$ differed quantitatively from apples in all other treatments, including those heated.
\end{abstract}

Various apple postharvest treatments that maintain fruit quality and reduce losses due to decay-causing pathogens have been investigated. Heating apples before storage has been used with inconsistent results. In most early studies of prestorage heating, apples were immersed in hot water to reduce losses caused by postharvest pathogens (Burchill, 1964; Sharples, 1967). Immersing apples in water at 45C reduced Gloeosporium decay but increased tissue breakdown. However, adding $\mathrm{CaCl}_{2}$ to the hot water controlled tissue breakdown and fungi (Sharples and Johnson, 1976). Later investigations on prestorage heating involved using hot air. Porritt and Lidster (1978) exposed 'Spartan' and 'Golden Delicious' apples to $38 \mathrm{C}$ for 4 to 6 days and stored them at $-1 \mathrm{C}$ for 4 to 7 months. Fruit softening was suppressed and naturally occurring decay, mostly due to Corticium and Penicillium spp., was reduced. Liu (1978) found that storage at 40C for 2 to 4 days also suppressed softening of 'Golden Delicious' fruit. More recently, Klein et al. (1990) heated 'Anna' or 'Granny Smith' fruit at $38 \mathrm{C}$ for 4 days and dipped the fruit in $2 \% \mathrm{CaCl}_{2}$ at either $20 \mathrm{C}$ or $38 \mathrm{C}$, or heated fruit at $38 \mathrm{C}$ for 4 days after dipping them in $2 \%$ $\mathrm{CaCl}_{2}$ at $20 \mathrm{C}$. The best heat treatment was exposure to $38 \mathrm{C}$ for 4 days; a $\mathrm{CaCl}_{2}$ dip before heating appreciably enhanced the effect of heating. Calcium chloride alone also has maintained firmness and reduced decay caused by $P$. expansum (Conway and Sams, 1983; Sams and Conway, 1984) in 'Golden Delicious' apples, especially when $\mathrm{CaCl}_{2}$ was pressure-infiltrated into the fruit. However, several researchers have commented privately that the texture of $\mathrm{CaCl}_{2}$ treated apples was somehow "different" from normal apples. Apple firmness traditionally is measured as the maximum force

Received for publication 19 Feb. 1992. Accepted for publication 13 Jan. 1993. We express our appreciation to George A. Brown, William B. Beavers, and J. Norman Livsey for valuable technical assistance. The cost of publishing this paper was defrayed in part by the payment of page charges. Under postal regulations, this paper therefore must be hereby marked advertisement solely to indicate this fact. to push a manually operated Magness-Taylor (MT) fruit firmness probe (Ballauf Manufacturing Co., Laurel, Md.) of specified shape a distance of $7.9 \mathrm{~mm}$ into the pared flesh. Another nearly identical tester is the Effe-gi (Effe-gi, Ravenna, Italy). Speed and penetration depth are controlled manually. The MT detects the maximum force developed at any distance during the probe's penetration. Bourne (1965) showed that, in apples, the maximum force during penetration can occur at any depth from bioyield (initial tissue failure) to maximum penetration. Bourne (1974) and others have used the standard MT probe in a universal testing machine (Instron Corp., Canton, Mass.), which controls speed and distance of probe movement and displays force vs. deformation (FD) during measurement. Abbott et al. (1976) interfaced an Instron with a computer to record force vs. deformation curves and extract data electronically.

There have been several adaptations of the MT probe. One is the electronic pressure tester (EPT) (model EPT-1; Lake City Technical Products, Kelowna, B.C., Canada). The speed of probe application in the EPT is controlled manually, but the instrument rejects tests made at too high or too low a speed. The EPT detects the bioyield force rather than the maximum force. The discrepancy between results from the MT and EPT can be explained mostly by the difference in the features measured.

The main objective of this investigation was to compare the effectiveness of postharvest heat and $\mathrm{CaCl}_{2}$ treatments to maintain firmness and reduce decay caused by $P$. expansum. An additional objective was to seek evidence for textural differences due to $\mathrm{CaCl}_{2}$, heating, or both.

\section{Materials and Methods}

'Golden Delicious' apples were harvested in the preclimacteric stage (as indicated by $\mathrm{CO}_{2}$ and ethylene production) from two commercial orchards and randomized into 10 equal lots. Five lots 
were treated in one of the following ways: 1) no treatment (control), 2) dipped in distilled water for $3 \mathrm{~min}, 3$ ) dipped in a $4 \%$ $\mathrm{CaCl}_{2}$-distilled water solution (w/v) for $\left.3 \mathrm{~min}, 4\right)$ pressure-infiltrated for $3 \mathrm{~min}$ at $103 \mathrm{kPa}$ with distilled water, or 5) pressureinfiltrated for $3 \mathrm{~min}$ at $103 \mathrm{kPa}$ with $4 \% \mathrm{CaCl}_{2}$. Following treatment, the fruit were placed on clean, white paper and allowed to air dry before being stored at 0C. Five other fruit lots were placed in tray-packed boxes with perforated polyethylene bags as liners and heated for 4 days at $38 \mathrm{C}$. The fruit lots were removed from the heating chamber, subjected to the same five treatments as the first five fruit lots, and air-dried on clean, white paper before being stored at $0 \mathrm{C}$. Apples were removed from storage after 6 months and tested for disease severity, Ca content, and firmness. The results from the two experiments were pooled.

To test the combination of $\mathrm{CaCl}_{2}$ and heating, a randomized complete-block design with three replications of each of the following 10 treatments was used: 1) no treatment (control) 2) heated for 4 days at 38C, 3) dipped for 3 min in distilled water, 4) dipped for $3 \mathrm{~min}$ in distilled water after heating, 5) pressure-infiltrated for $3 \mathrm{~min}$ at $103 \mathrm{kPa}$ with distilled water, 6) pressure-infiltrated for 3 min at $103 \mathrm{kPa}$ with distilled water after heating, 7) dipped for 3 min in $4 \% \mathrm{CaCl}_{2}, 8$ ) dipped for 3 min in $4 \% \mathrm{CaCl}_{2}$ after heating, 9) pressure-infiltrated for $3 \mathrm{~min}$ at $103 \mathrm{kPa}$ with $4 \% \mathrm{CaCl}_{2}$, and 10 ) pressure-infiltrated for $3 \mathrm{~min}$ at $103 \mathrm{kPa}$ with $4 \% \mathrm{CaCl}_{2}$ after heating.

Disease severity. Twenty fruit from each replication of each treatment were inoculated with $P$. expansum, wounded on two sides to a depth of $2 \mathrm{~mm}$ by pressing them down on the head of a nail $2 \mathrm{~mm}$ in diameter, immersed for $15 \mathrm{sec}$ in a distilled water conidial suspension ( $10^{5}$ spores $/ \mathrm{ml}$ ), and held at 20C for 7 days. The apples were rated for decay severity by measuring the surface diameter of the decayed area as the mean of its width and length and then calculating the area of decay.

Calcium content analysis. Calcium content of the apple tissue was determined by removing the peel and outer flesh of the entire fruit to a depth of $2 \mathrm{~mm}$ with a mechanical peeler. This layer was discarded. The next $2 \mathrm{~mm}$ of flesh tissue was removed, again with the mechanical peeler, and used for the analysis. The flesh from five apples made up one sample; four samples from each replication of each treatment were analyzed. After being removed, the fruit flesh was frozen immediately in liquid $\mathrm{N}$, freeze-dried, and ground. From each sample, $1 \mathrm{~g}$ of dried material was ashed, dissolved in $5 \mathrm{ml} 2 \mathrm{~N} \mathrm{HCl}$, and filtered. The samples were analyzed for $\mathrm{Ca}$ content by plasma emission spectrophotometry. All Ca values are reported on a dry-weight basis.

Firmness measurements. Two trays (20 fruit each) of apples from each replication of each treatment were placed at 20C overnight for MT testing. Apples from one tray were tested with an MT with an EPT; the others were tested with an MT with an Instron.

The EPT was set in the MT mode and interfaced with a personal computer. EPT firmness was measured at two opposite points on the equator of each fruit. Skin was removed with a fixed blade slicer that removed a slice $\approx 2 \mathrm{~mm}$ thick at the center. EPT readouts on two sites were averaged and converted to Newtons after analysis. The EPT detects the bioyield force, which is not necessarily the maximum force during penetration.

Instron firmness measurements were made using a standard MT probe in an Instron interfaced with and controlled by a personal computer (Abbott et al., 1983, 1984). The speed of probe movement was controlled mechanically at $12.7 \mathrm{~mm} \cdot \mathrm{min}^{-1}$, which is about half the speed recommended for manual MT measurements (Blanpied et al., 1978). Punctures were made on two opposite manually pared sites. The apple was held in a bevelled holder during puncture to prevent bruising the opposite site. The Instron was programmed to move the probe $7.92 \mathrm{~mm}$ after contact with the flesh, regardless of the actual penetration depth. If the whole apple deformed significantly before sufficient force developed to cause tissue rupture and penetration (before bioyield occurred), the probe would not penetrate a full $7.9 \mathrm{~mm}$ although it traveled that distance; i.e., part of the $7.9 \mathrm{~mm}$ would be in compression and the rest in penetration. Complete FD curves were recorded by the computer and analyzed later for maximum force $\left(\mathrm{F}_{\max }\right)$, fracture forces $\left(\mathrm{F}_{\mathrm{frc}}\right)$, average force midway between the distance at $\mathrm{F}_{\mathrm{frc}}$ and full displacement $\left(\mathrm{F}_{\text {mid }}\right)$, force at full $7.9 \mathrm{~mm}$ displacement $\left(\mathrm{F}_{\text {full }}\right)$, slope at $0.5 \mathrm{~F}_{\text {frc }}\left(\mathrm{M}_{\mathrm{frc}}\right)$, slope at $0.5 \mathrm{~mm}$ deep in the flesh $\left(\mathrm{M}_{0.5 \mathrm{~mm}}\right)$, and other forces analyzed but not reported (Abbott et al., 1984).

The design was pseudofactorial, with heat treatments, $\mathrm{CaCl}_{2}$ application methods, and $\mathrm{Ca}$ concentrations, plus single controls for no heat and heat. Experimental units for firmness measurements were individual apples.

\section{Results}

Decay. The area of decay on fruit from treatments 3, 5, and 7 was similar to that of the control fruit (treatment 1) in that decay was reduced little by dipping-or pressure-infiltration with distilled water or dipping in $4 \% \mathrm{CaCl}_{2}$ (Fig. 1). Fruit from treatments 2, 4, 6 , and 8 had $\approx 30 \%$ less decayed area than the control fruit, a result indicating that heating reduced pathogenesis by $P$. expansum. Heating followed by pressure-infiltrating $4 \% \mathrm{CaCl}_{2}$ (treatment 10) resulted in less decayed area than the other heat treatments $(\approx 40 \%$ less than the control). Fruit pressure-infiltrated with $4 \% \mathrm{CaCl}_{2}$ (treatment 9) had the smallest area of decay $(>60 \%$ less than the control).

Calcium content. Treatments 1 through 6 resulted in a tissue $\mathrm{Ca}$ concentration of $\approx 150 \mathrm{~g} \mathrm{Ca} / \mathrm{g}$ dry weight (Fig. 2). Fruit from treatment 7 contained $308 \mu \mathrm{g} \cdot \mathrm{g}^{-1}$, those from treatment 8 contained $252 \mu \mathrm{g} \cdot \mathrm{g}^{-1}$, those from treatment 10 contained an average of 565 $\mu \mathrm{g} \cdot \mathrm{g}^{-1}$, and those from treatment 9 (pressure-infiltrated with $4 \%$ $\mathrm{CaCl}_{2}$ ) had the highest Ca concentration-1618 $\mu \mathrm{g} \cdot \mathrm{g}^{-1}$. Fruit from treatment 9 were the only ones with superficial injury to the peel.

Firmness. The effect of the various treatments on fruit firmness was inverse to that on decay. Firmness, as measured with the EPT, of fruit from treatment 1 (control), 3, 5, and 7 averaged $\approx 60 \mathrm{~N}$ (Fig. 3.) The heat-treated fruit from treatments $2,4,6$, and 8 averaged 71 $\mathrm{N}$. Fruit from treatment 10 , heat followed by $\mathrm{CaCl}_{2}$ pressure infiltration, averaged $76 \mathrm{~N}$. The firmest fruit $(\approx 84 \mathrm{~N})$ resulted from treatment 9 (pressure-infiltrating $4 \% \mathrm{CaCl}_{2}$ ).

The differences between control and heated fruit were even more evident in the forces developed in the Instron $\left(\mathrm{F}_{\text {max }}\right.$ and $\left.\mathrm{F}_{\text {mid }}\right)$ than in the EPT, but the preheating effect of treatment 10 (heat followed by pressure-infiltrating $4 \% \mathrm{CaCl}_{2}$ ) was not evidenced by these force values, unlike with the EPT values. Instron FD curves segregated themselves by treatment group (Fig. 4). The FD curves for treatments $1,3,5$, and 7 were similar to each other and are represented by their mean (curve A). Similarly, treatments 2, 4, 6, 8 , and 10 are represented by curve B. The curve (C) for treatment 9 was distinct from the others, probably because significantly more Ca had entered the fruit than in the other treatments (Fig. 2). Still, the Instron clearly showed that treatment 9 (no heat, pressureinfiltrating $4 \% \mathrm{CaCl}_{2}$ ) had a steeper initial slope than the other treatments (Fig. 4). Although $\mathrm{F}_{\max }$ and $\mathrm{F}_{\text {mid }}$ values essentially were the same for treatment 9 and treatments 2, 4, 6, 8, and 10 (Table 1), the initial slopes and penetration at which the maxima occurred differed between these treatment groups (Fig. 4). For treatment 9, the maximum force was reached at the maximum penetration, whereas it occurred at the point of bioyield for treatments $2,4,6$, 


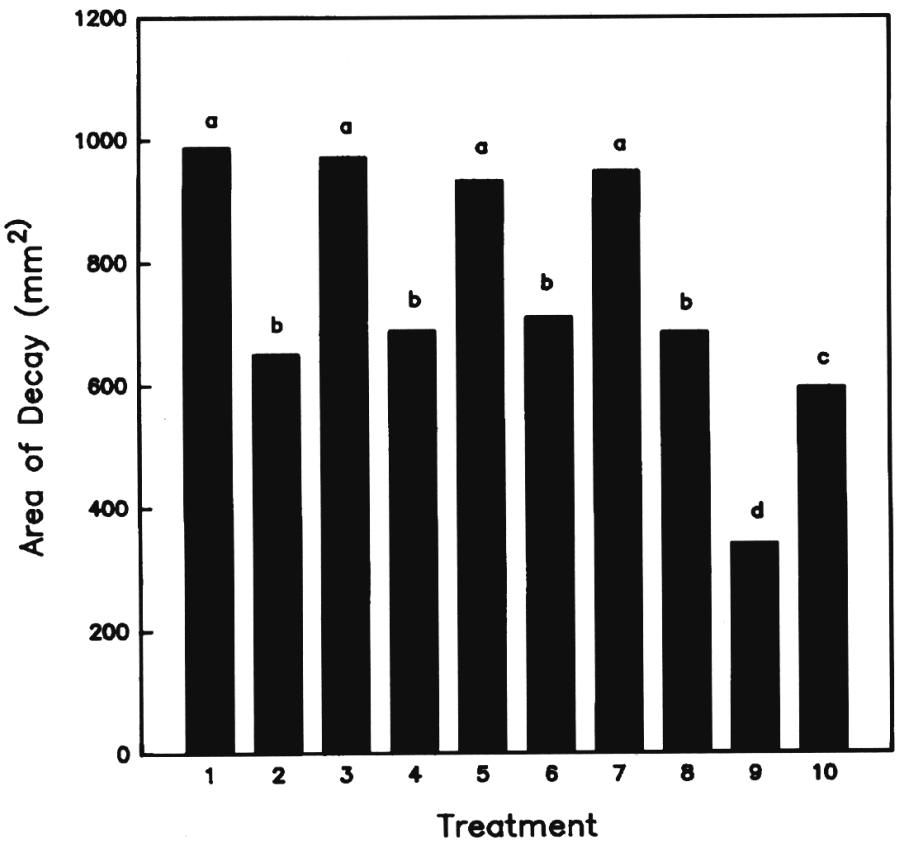

Fig. 1. Relationship between treatment and area of decay on 'Golden Delicious' apples inoculated with Penicillium expansum. Treatments are identified in Table 1. Mean separation by Duncan's multiple range test, $P \leq 0.05$.

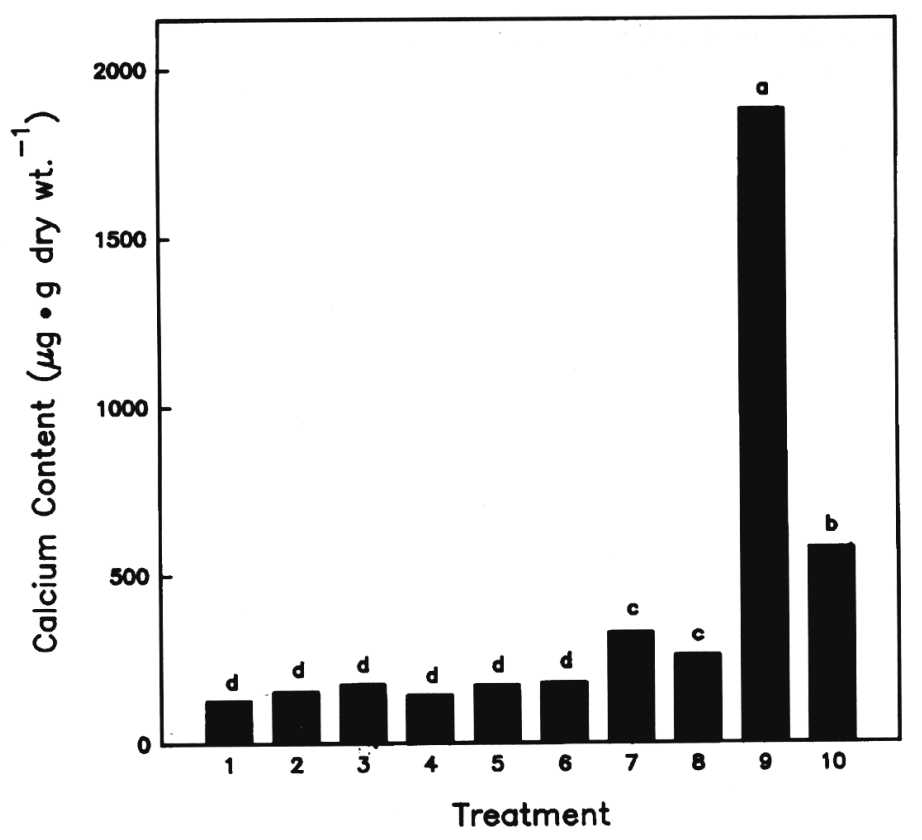

Fig. 2. Relationship between Ca content and treatment of 'Golden Delicious' apples. Treatments are identified in Table 1. Mean separation by Duncan's multiple range test, $P=0.05$.

8 , and 10 (curve B). The elasticity or rigidity of apple flesh is indicated by the slope of the initial portion of the PD curves before the elastic limit is exceeded. The slopes of apples in treatments $1,3,5$, and 7 (curve A) andtreatments 2, 4, 6, 8, and 10 (curve B) were similar. The slopes of the apples in treatment 9 (curve C) were much steeper than the others, as evidenced by the mean slope values, as expressed as Newtons per millimeter (Table 1). There was a clear separation of the bands formed by the initial slopes of curve $\mathrm{C}$ (treatment 9 ) and curve A (treatments $1,3,5$, and 7) or curve B (treatments 2, 4, 6, 8, and 10) when Instron FD curves for all apples were plotted together.

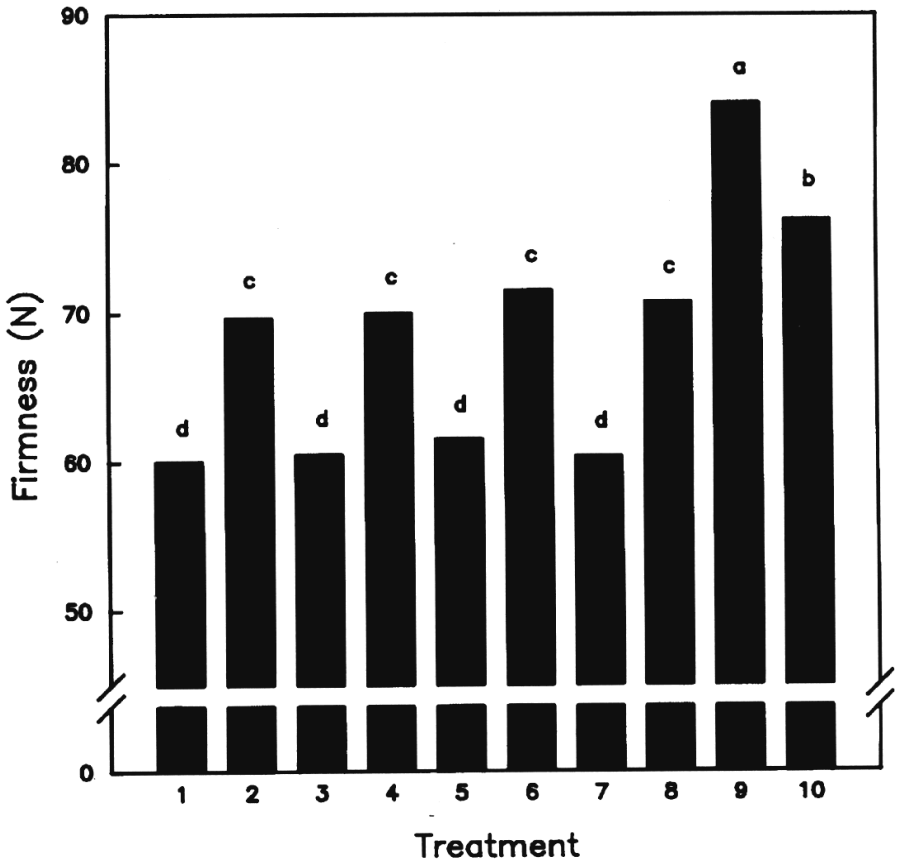

Fig. 3. Relationship between firmness measured with an electronic pressure tester and treatment of 'Golden Delicious' apples. Treatments are identified in Table 1. Mean separation by Duncan's multiple range test, $P \leq 0.05$.

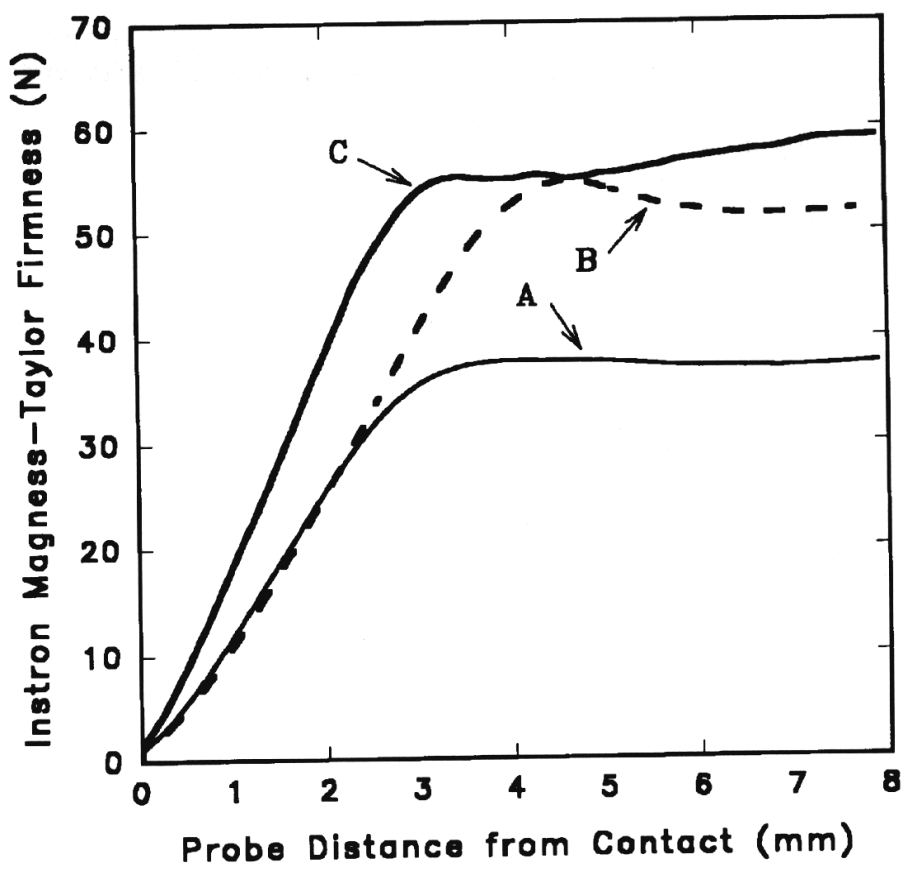

Fig. 4. Force vs. deformation curves for 'Golden Delicious' apples that received various postharvest treatments and were stored for 6 months in air at 0C. Treatments are identified in Table 1. (A) Treatments 1,3,5, and 7; (B) treatments $2,4,6,8$, and $10 ;(C)$ treatment 9 .

\section{Discussion}

The heat and $\mathrm{Ca}$ treatments reduced decay and maintained firmness in the stored apples, although not to the same extent. Calcium chloride infiltration was more effective than heating in reducing decay and maintaining fruit firmness. The effect $\mathrm{Ca}$ has on decay and firmness is thought to be related to the tight binding of $\mathrm{Ca}$ ions in the cell wall (Demarty et al., 1984). Pectins are 
Table 1. Treatment summary and force vs. deformation results for 'Golden Delicious' apples stored for 6 months at $0 \mathrm{C}$ after various heat and $\mathrm{Ca}$ treatments.

\begin{tabular}{|c|c|c|c|c|c|c|}
\hline \multirow[b]{3}{*}{ Treatment } & \multicolumn{3}{|c|}{ Treatment conditions } & \multirow{2}{*}{\multicolumn{3}{|c|}{$\begin{array}{c}\text { Responses } \\
\text { Force vs. deformation }^{\mathrm{x}}\end{array}$}} \\
\hline & \multirow{2}{*}{$\begin{array}{l}\text { Heated } \\
\text { at } 38 \mathrm{C} \\
\text { (days) }\end{array}$} & \multirow[b]{2}{*}{$\begin{array}{c}\text { Pressure } \\
\text { infiltration } \\
\text { z,y }\end{array}$} & \multirow{2}{*}{$\begin{array}{c}\mathrm{CaCl}_{2} \\
\text { solution } \\
(\%)\end{array}$} & & & \\
\hline & & & & $\begin{array}{l}\mathrm{F}_{\max } \\
(\mathrm{N})\end{array}$ & $\begin{array}{l}\mathrm{F}_{\text {mid }} \\
(\mathrm{N})\end{array}$ & $\begin{array}{l}\mathrm{M}_{0.5 \mathrm{~mm}} \\
(\mathrm{~N} / \mathrm{mm})\end{array}$ \\
\hline 1 & 0 & None & None & 40 & 36 & 7.68 \\
\hline 2 & 4 & None & None & 60 & 50 & 6.28 \\
\hline 3 & 0 & Dip & 0 & 42 & 37 & 6.85 \\
\hline 4 & 4 & Dip & 0 & 64 & 52 & 7.04 \\
\hline 5 & 0 & Pressure & 0 & 40 & 35 & 8.70 \\
\hline 6 & 4 & Pressure & 0 & 55 & 47 & 8.10 \\
\hline 7 & 0 & Dip & 4 & 43 & 38 & 8.80 \\
\hline 8 & 4 & Dip & 4 & 60 & 51 & 7.52 \\
\hline 9 & 0 & Pressure & 4 & 63 & 56 & 13.28 \\
\hline 10 & 4 & Pressure & 4 & 66 & 55 & 7.18 \\
\hline
\end{tabular}

${ }^{\bar{z}}$ All dips were for $3 \mathrm{~min}$; when dips were combined with heating, dipping came second.

${ }^{\mathrm{y}}$ Pressure infiltration was for $3 \mathrm{~min}$ at $103 \mathrm{kPa}$; when infiltration was combined with heating, infiltration came second.

${ }^{\mathrm{x}} \mathrm{F}_{\max }=$ maximum force, $\mathrm{F}_{\text {mid }}=$ force midway between the distance at bioyield and full displacement, $\mathrm{M}_{0.5 \mathrm{~mm}}=$ slope at $0.5 \mathrm{~mm}$ deep in the flesh.

composed of polygalacturonic acid residues in a chain with rhamnose interspersed in the chain (Preston, 1979). The resulting bunched configuration of the polygalacturonic chain caused by the rhamnose allows spaces for a series of cations (Grant et al., 1973), of which Ca is inserted preferentially (Demarty et al., 1978, 1984). The formation of cation cross-bridges between uronic acids may make the cell wall less accessible to enzymes in the fruit that cause softening or to cell wall-degrading enzymes produced by fungal pathogens. Calcium decreases the amount of soluble polyuronides present in apples after storage (Sams and Conway, 1984). Increasing the $\mathrm{Ca}$ content of apple cell walls has been shown to offer protection from maceration by polygalacturonase produced by $P$. expansum (Conway et al., 1988). Previous studies (Conway and Sams, 1985, 1987) have shown that, to reduce decay caused by $P$. expansum in apple consistently by $\approx 50 \%$ or more, fruit tissue concentration must be increased to $\approx 1200$ to $1500 \mu \mathrm{g} \mathrm{Ca} / \mathrm{g}$ dry weight. In a recent study in which the Ca concentration of 'Delicious' apple fruit was increased to just over $1000 \mu \mathrm{g} \cdot \mathrm{g}^{-1}$, decay caused by $P$. expansum was reduced by $<40 \%$ (Conway et al., 1991). Decay caused by Botrytis cinerea Pers. Fr. and Glomerella cingulata (Stoneman) Spauld. \& H. Schrenk, however, was reduced by a significantly greater amount, indicating that a given tissue $\mathrm{Ca}$ concentration has a greater effect on these two postharvest pathogens than on $P$. expansum. The combination of heating followed by dipping in $\mathrm{CaCl}_{2}$ in this study resulted in slightly less decay than heat alone, probably because the $\mathrm{Ca}$ tissue concentration of the fruit infiltrated with $\mathrm{CaCl}_{2}$ was increased only to $\approx 600$ $\mu \mathrm{g} \cdot \mathrm{g}^{-1}$, or only $\approx 50 \%$ of the desirable range needed for $\mathrm{Ca}$ to reduce decay appreciably. In contrast, pressure infiltrating $4 \% \mathrm{CaCl}_{2}$ without heat increased $\mathrm{Ca}$ fruit concentration to $>1700 \mu \mathrm{g} \cdot \mathrm{g}^{-1}$ and reduced area of decay by $>60 \%$. However, when the desired optimum Ca concentration range of $\approx 1400 \mu \mathrm{g} \cdot \mathrm{g}^{-1}$ is exceeded, fruit injury results, as evidenced in this study. Apples in our study were pressure-infiltrated with $4 \% \mathrm{CaCl}_{2}$, either at harvest or after being heated at $38 \mathrm{C}$ for 4 days. The fruit-tissue $\mathrm{Ca}$ concentration increased to $>1700 \mu \mathrm{g} \cdot \mathrm{g}^{-1}$ in the fruit lot treated at harvest, but only to $\approx 600 \mu \mathrm{g} \cdot \mathrm{g}^{-1}$ in fruit treated after 4 days at $38 \mathrm{C}$. It seems, therefore, that the structures in the fruit surface through which the $\mathrm{CaCl}_{2}$ solution enters are affected by heating. Although $\mathrm{Ca}$ from postharvest treatments with $\mathrm{CaCl}_{2}$ is thought to enter primarily through the lenticels (Betts and Bramlage, 1977), cracks in the cuticle and epidermis also may provide pathways (Clements, 1935). 'Golden Delicious' fruit have an especially high degree of cracking in the cuticle and skin (Meyer, 1944). Possibly, heating "melted" the wax into the cracks, thereby plugging up this important entry pathway and not allowing as much Ca to enter the fruit, resulting in a significantly smaller increase in tissue $\mathrm{Ca}$ compared to the fruit pressure-infiltrated with $\mathrm{CaCl}_{2}$ solutions and not heated.

The mechanism by which heating may affect the cell wall and, thus, resulted in less decay and maintained fruit firmness is not clear. In a study comparing the effects of heating with $\mathrm{CaCl}_{2}$, infiltration on firmness, heating for 4 days at $38 \mathrm{C}$ before storage had the greatest affect on firmness (Klein et al., 1990). Calcium was applied by dipping in $2 \% \mathrm{CaCl}_{2}$ at $38 \mathrm{C}$, and the resulting increase in $\mathrm{Ca}$ concentration of the cortex was $\approx 44 \%$. The results on the effect of heating or $\mathrm{CaCl}_{2}$ infiltration on decay and firmness reported by us indicate that $\mathrm{Ca}$ was more effective in reducing decay and maintaining firmness than heat. However, in our study, $\mathrm{CaCl}_{2}$ was pressure-infiltrated into the fruit, a procedure that resulted in a much greater increase in $\mathrm{Ca}$ concentration of the cortex than was reported by Klein et al. (1990). This increase in Ca concentration resulted in a greater reduction in decay and better maintenance of firmness than heating.

As noted, Ca may decrease decay-induced softening by cellwall macerating enzymes produced by plant pathogens through the formation of Ca-pectate in the cell wall. Possibly, as in fruit heated during processing, endogenous $\mathrm{Ca}$ is used to form Ca-pectate by the heat-enhanced activity of pectinesterase. The cell walls thus affected would then be more resistant to breakdown by cell walldegrading enzymes. In our study, additional $\mathrm{Ca}$ was pressureinfiltrated after heating. The effect of the heat may have caused a physical blockage of pathways by which $\mathrm{CaCl}_{2}$ solutions entered the apples, so that much less $\mathrm{Ca}$ entered than in nonheated fruit. Also, the increase in pectinesterase activity may occur only during heating, followed by a reduction in activity after treatment is discontinued. Infiltrating $\mathrm{Ca}$ into the fruit should precede heating, thereby substantially increasing the Ca concentration of the apple cortical tissue before heating effectively blocks off some of the entry pathways. If the activity of pectinesterase is enhanced only during heating, the exogenously supplied $\mathrm{Ca}$ will be present to be 
used to form Ca-pectate, an action that will increase decay resistance and maintain firmness. However, a negative aspect of increasing $\mathrm{Ca}$ before heating exists. If heat-enhanced activity of pectinesterase is responsible for stabilizing the cell wall and making it more resistant to enzymes causing softening and decay, the large increase in $\mathrm{Ca}$ actually may decrease pectinesterase activity, as has been shown in at least one study (Laufman et al., 1989). The effect of greatly increasing the Ca concentration of the cortex before heating on decay and firmness remains to be shown.

Combining heating and $\mathrm{CaCl}_{2}$ infiltration would be desirable so that the $\mathrm{Ca}$ concentration would not exceed the optimum range limit of 1200 to $1400 \mu \mathrm{g} \cdot \mathrm{g}^{-1}$, wherein a $50 \%$ decay reduction could be realized plus an additional reduction in decay as a result of the additive effects of heating. In this way, the injury caused by excess $\mathrm{Ca}$ could be avoided while still realizing a more significant reduction in decay.

In conclusion, this study has demonstrated that heating reduced decay caused by $P$. expansum and that adding $\mathrm{Ca}$ further improved this effect. The data also suggest that, although heating and $\mathrm{Ca}$ maintain firmness, they have different effects on fruit texture. We suggest that the differences in Instron FD curves would be detectable as sensory textural differences, although the relationship of FD data to human response is not fully established. We further suggest that apples with a steeper slope would be perceived as firmer to the hand and harder to the bite than apples with a lower slope. Those with higher $\mathrm{F}_{\text {mid }}$ likely would seem tougher to bite and chew than others with similar $\mathrm{F}_{\max }$ values. In this case, apples heated before storage or pressure-infiltrated with $\mathrm{CaCl}_{2}$ would seem tougher than apples from treatments $1,3,5$, or 7 . Consumer acceptance of both treatments needs to be evaluated before their implementation.

\section{Literature Cited}

Abbott, J.A., D.R. Massie, and A.E. Watada. 1983. The use of a computer with an Instron for textural measurements. J. Texture Studies 13:413422.

Abbott, J.A., A.E. Watada, and D.R. Massie. 1976. Effe-gi, Magness-Taylor, and Instron fruitpressure testing devices for apples, peaches, and nectarines. J. Amer. Soc. Hort. Sci. 101:698-700.

Abbott, J.A., A.E. Watada, and D.R. Massie. 1984. Sensory instrument measurement of apple texture. J. Amer. Soc. Hort. Sci. 109:221-228.

Betts, H.A. and W.J. Bramalage. 1977. Uptake of calcium by apples from postharvest dips in calcium chloride solutions. J. Amer. Soc. Hort. Sci. 102:785-788.

Blanpied, G.D., W.J. Bramlage, D.H. Dewey, R.L. LaBelle, L.M. Massey, Jr., G.E. Mattus, W.C. Stiles, and A.E. Watada. 1978. A standardized method for collecting apple pressure test data. New York Food and Life Sci. Bul. 74.

Bourne, M.C. 1965. Studies on punch testing of apples. Food Technol. 19:113-115.
Bourne, M.C. 1974. Comparison of results from the use of the Magness-Taylor pressure tip in hand- and machine-operation. J. Texture Studies 5:105-108.

Burchill, R.T. 1964. Hot water as a possible post-harvest control of Gloeosporium rots of stored apples. Plant Pathol. 13:106-107.

Clements, H.F. 1935. Morphology and physiology of the pome lenticels of Pyrus malus. Bot. Gaz. 97: 101-117.

Conway, W.S., K.C. Gross, C.D. Boyer, and C.E. Sams. 1988. Inhibition of Penicillium expansum polygalacturonase activity by increased apple cell wall calcium. Phytopathology 78:1052-1055.

Conway, W.S. and C.E. Sams. 1983. Calcium infiltration of Golden Delicious apples and its effect on decay. Phytopathology 73: 1068-1071.

Conway, W.S. and C.E. Sams. 1985. Influence of fruit maturity on the effect of postharvest calcium treatment on decay of Golden Delicious apples. Plant Dis. 69:42-44.

Conway, W.S. and C.E. Sams. 1987. The effects of postharvest infiltration of calcium, magnesium, or strontium on decay, firmness, respiration, and ethylene production in apples. J. Amer. Soc. Hort. Sci. 112:300-303.

Conway, W.S., C.E. Sams, J.A. Abbott, and B.D. Bruton. 1991. Postharvest calcium treatment of apple fruit to provide broad-spectrum protection against postharvest pathogens. Plant Dis. 75:620-622.

Demarty, M., C. Morvan, and M. Thellier. 1978. Exchange properties of isolated cell walls of Lemna minor L. Plant Physiol. 62:477-481.

Demarty, M., C. Morvan, and M. Thellier. 1984. Calcium and the cell wall. Plant Cell Environ. 7:441-448.

Grant, G.T., E.R. Morris, D.A. Rees, P.J.C. Smith, and D. Thorn. 1973. Biological interactions between polysaccharides and divalent cations: The egg-box model. Federation European Biochem. Societies Lett. 32:195-198.

Klein, J.D., S. Lurie, and R. Ben-Arie. 1990. Quality and cell wall components of 'Anna' and 'Granny Smith' apples treated with heat, calcium, and ethylene. J. Amer. Soc. Hort. Sci. 115:954-958.

Laufmann, J.D., C.E. Sams, and W.S. Conway. 1989. Pectin methyl esterase activity in 'Golden Delicious' apples as affected by postharvest calcium treatments. HortScience 24:59. (Suppl.)

Liu, F.W. 1978. Modification of apple quality by high temperature. J. Amer. Soc. Hort. Sci. 103:730-732.

Meyer, A. 1944. A study of the skin structure of 'Golden Delicious' apples. Proc. Amer. Soc. Hort. Sci. 45:723-727.

Porritt, S.W. and P.D. Lidster. 1978. The effect of pre-storage heating on ripening and senescence of apples during cold storage. J. Amer. Soc. Hort. Sci. 103:584-587.

Preston, R.D. 1979. Polysaccharide formation and cell wall function. Annu. Rev. Plant Physiol. 30:55-78.

Sams, C.E. and W.S. Conway. 1984. Effect of calcium infiltration on ethylene production, respiration rate, soluble polyuronide content, and quality of 'Golden Delicious' apple fruit. J. Amer. Soc. Hort. Sci. 109:53-57.

Sharples, R.O. 1967. The effect of postharvest-heat treatment on the storage behavior of Cox's Orange Pippin apple fruits. Ann. Applied Biol. 59:401-406.

Sharples, R.O. and D.S. Johnson. 1976. Postharvest chemical treatments for control of storage disorders of apples. Ann. Applied Biol. 83:157-167. 